\title{
СПЕЦИФИЧНИ ТЕШКОТИИ ВО УЧЕЊЕТО КАЈ УЧЕНИЦИТЕ - ДИСЛЕКСИЈА
}

\section{Кратка содржина}

Дислексијата е тема за дебата која трае со десетици години и сѐ уште продолжува да биде предмет на дискусија. Британската асочијаџија за дислексија најдобро ја дефинира дислексијата како комбиначија на способности и тешкотии кои влијаат на прочесот на читање, спелување и пишување. Со нив се поврзани слабостите како што се брзина на процесирање на информачијата, краткотрајна меморија, концентрачија, секвенционирање и организачија, аудитивна и/или визуелна перцепџија, говорен јазик и моторни вештини.

Во нашата земја, македонското Здружение за дислексија „Ајнитајн“ во 2015 година изврши тестирање на 782 ученичи од две средни училишта во Скопје. Тестот со кој учениците вриеа самопрочена на дислексијата беше преземен од Листата за проверка на дислексија од авторите Кавклер, Магајна, Кочак Бадуер, Јанзељ, Андрејчик и Земјак. Добиените одговори покажуваат дека околу 10\% од ученииите ги манифестираат знаците на дислексија. Овој податок укажува на потребата од дејствување на полето на дислексијата со цел да се олеснат тешкотиите во учењето кај учениџите со дислексија во Република Македонија.

Клучни зборови: ТЕШКОТИИ ВО УЧЕЊЕТО, ДИСЛЕКСИЈА, УЧЕНИЦИ

\section{Вовед}

Тешкотиите во учењето се однесуваат на специфични попречености што го оневозможуваат разбирањето и употребата на јазикот и на пречки во говорот, читањето и пишувањето. Според досегашните истражувања, се проценува дека речиси $5 \%$ од популацијата на учениците се деца со такви тешкотии и тоа околу четири пати повеќе кај момчињата отколку кај девојчињата.

Треба да се знае дека децата со такви тешкотии не се ментално заостанати, сензорно оштетени, ниту имаат емоционални пречки. Кај одредувањето на таквите пречки е важно да се направи разлика помеѓу делотворните интелектуални потенцијали и вистинската изведба. Притоа, треба да се исклучи влијанието на останатите надворешни и внатрешни фактори кои би можеле да предизвикаат слаб училиштен успех. Некои автори сметаат дека во категоријата на децата со специфични тешкотии во учењето можат да се сметаат деца кои имаат просечен (или натпросечен) коефициент на интелигенција, а во училишниот успех заостануваат во одредени предмети, две одделенија по своите врсници (Kirk \& Galagher, 1989, според Vizek-Vidović, 2003). Во колкава мерка овие пречки се независни од општата ментална развиеност зборуваат биографските податоци за многу значајни лу- 
ŕe кои во младоста пателе од специфични тешкотии во учењето. Така, на пример, се знае дека Алберт Ајнштајн и Томас Едисон биле дислексичари кои многу тешко научиле да читаат, додека Ханс Кристијан Андерсен бил дисграфичар со изразени тешкотии во пишувањето. Сите тие едвај се провлекувале во училиште. Поновите сознанија во тој поглед зборуваат дека во заднината на тешкотијата во учењето се наоѓаат специфични развојни пречки кои треба навреме да се воочат за да се одбегне прогласување на детето за ментално заостанато. Развојните пречки може да бидат: тешкотии во вниманието, пречки во мислењето и помнењето, тешкотии во говорот и перцептивни и моторни пречки. Тие водат кон тешкотии во учењето, како што се: тешкотии во читањето, во пишувањето, во изразувањето и во сметањето. Особено е важно да се нагласи дека таквите тешкотии во учењето речиси секогаш предизвикуваат училиштен неуспех, но и секој училиштен неуспех не мора да биде предизвикан од специфичните тешкотии во учењето.

\section{Дефинирање на дислексијата}

Зборот дислексија потекнува од грчкиот збор „dуs-“ што значи тешкотија и „lexis“ што значи јазик, или дислексија може да има значење „тешкотии со зборови“. Постојат многу дефиниции поставени од различни истражувачи на дислексијата, но формална дефиниција е поставена од посебни групи, како што се: Британска асоцијација за дислексија, Британско психолошко здружение, Меѓународно здружение за дислексија (British Dyslexia Association, The British Psychological Society, International Dyslexia Association). Со анализа на овие дефиниции се добиени две главни категории: причински и дескриптивни дефиниции. Причинските дефиниции се произлезени од истражувањата на невролошките и биолошките причини на дислексијата. Тие се засноваат на разликите во функционирањето на мозокот кои ја предизвикуваат дислексијата. Односно, нивниот дефицит во функционирањето на мозокот се согледува во процесирањето и интерпретацијата на информацијата која доаѓ од сетилата. Дескриптивните дефиниции се засновани на манифестациите на дислексијата. Овие дефиниции ги истакнуваат тешкотиите во процесите на читање, пишување и генерална организација на секојдневните задачи. Во описот на слабостите на ниво на когнитивното функционирање се вклучува и фонолошкиот процес и работната меморија, која е ограничена од дислексијата.

Светската федерација на невролози ја дефинира дислексијата и преку причините и преку опишувањето. Според неа, дислексија е нарушување кај децата кои, покрај конвенционалниот начин на учење, не се оспособуваат за јазични вештини на читање, пишување, согласно со нивните интелектуални способности. Зборот нарушување имплицира медицинско нарушување, што е основа на дефиницијата на овие автори.

Меѓународната асоцијација на дислексија ја дефинира дислексијата како специфични тешкотии во учењето кои се во основа невролошки и често наследни. Се карактеризира со точност и флуентност во препознавање на зборови, но со тешкотии во читањето или декодирањето. Овие тешкотии обично се резултат на 
дефицит во фонолошката компонента на јазикот, што е често во релација со други когнитивни компоненти и способности во училишната работа.

Британската асоцијација за дислексија најдобро ја дефинира дислексијата како комбинација на способности и тешкотии кои влијаат на процесот на учење помалку или повеќе во читање, спелување и пишување. Со нив се поврзани слабостите како што се брзина на процесирање на информацијата, краткотрајна меморија, концентрација, секвенционирање и организација, аудитивна и/или визуелна перцепција, говорен јазик и моторни вештини. Таа е особено поврзана со употребата на пишаниот јазик, што може да вклучи азбучни, нумерички или музички знаци. Некои од луѓето со дислексија имаат извонредни креативни способности, а некои имаат силни вербални способности. Некои немаат такви таленти. Тие се сите силни. Дислексијата може да се јави и покрај нормалните интелектуални способности и поучувањето.

\section{Природата на дислексијата}

Дислексијата најдобро се опишува како комбинација од способности и тешкотии кои се однесуваат на процесот на учење во неколку области: читање, спелување, пишување и некогаш во математика. Брзината на процесирање, краткотрајната или работна меморија, смислата за редослед, визуелната и аудитивната перцепција, говорниот јазик и моторичките вештини честопати се вештини кои им недостасуваат на учениците со дислексија. Истражувањата на оваа појава покажуваат дека дислексијата не зависи од интелигенцијата, од социоекономските услови, ниту, пак, од начинот на поучување, учениците со дислексија ги процесираат надворешните информации, пишани или говорни, на различен начин.

Дислексијата не е предизвикана од лоши училишта, не е предизвикана од лоша наставна практика, ниту, пак, од несовесни родители или, пак, од тешки услови за живот во домашната средина. Овие фактори може да ги направат работите потешки за детето со дислексија, но никако не можат да предизвикаат дислексија. Поради тоа, дислексијата не треба да се гледа како попреченост, туку како различен стил на учење. Установениот образовен систем не е доволно соодветен на стилот на учење на учениците со дислексија.

Според теоријата на Рон Дејвис (според Golubović \& Golubović, 2010), менталната функција која ја предизвикува дислексијата може да биде дарба во вистинска смисла на зборот: природна способност, талент. Ова не значи дека сите деца со дислексија ќе развијат таленти, но, сепак, сите тие имаат одредени заеднички ментални функции како што се: креативност, интуиција, размислување "out of box" и гледање на имагинарните слики како 3Д-проекции. Ова оди во прилог на теоријата дека лицата со дислексија доминантно ја користат десната хемисфера од мозокот преку која се контролирани токму овие карактеристики. Учениците со дислексија, најчесто, се бистри и креативни, ја гледаат големата слика на нештата наспроти деталите. Неретко се случува ученик со дислексија со забележителни симптоми на тешкотии во читањето и пишувањето да го знае одговорот на некое прашање или задача, а да не знае да објасни како дошол до решението. Ова доаѓа 
од холистичкиот пристап што го имаат и кој е карактеристичен за десната хемисфера од мозокот. Лицата со дислексија размислуваат доминантно со слики, а не вербално, поради што се соочуваат со дешифрирање на пишаните зборови, кои не претставуваат слики туку симболи за некој предмет, појава, активност, опис итн. Гледајќи во пишаниот симбол, на ученикот со дислексија му е потребна силна мозочна активност да го трансформира симболот во реална слика која ја бара неговиот начин на сликовито размислување. Именките, глаголите и придавките не претставуваат особен проблем. Познавајќи го говорниот јазик, тие ќе можат да ги претстават како слика овој вид зборови, но збунетоста настанува кога ќе наидат на кратките зборови, како што се сврзници, прилози и предлози, како и заменки. Интерпункциските знаци речиси и не ги забележуваат.

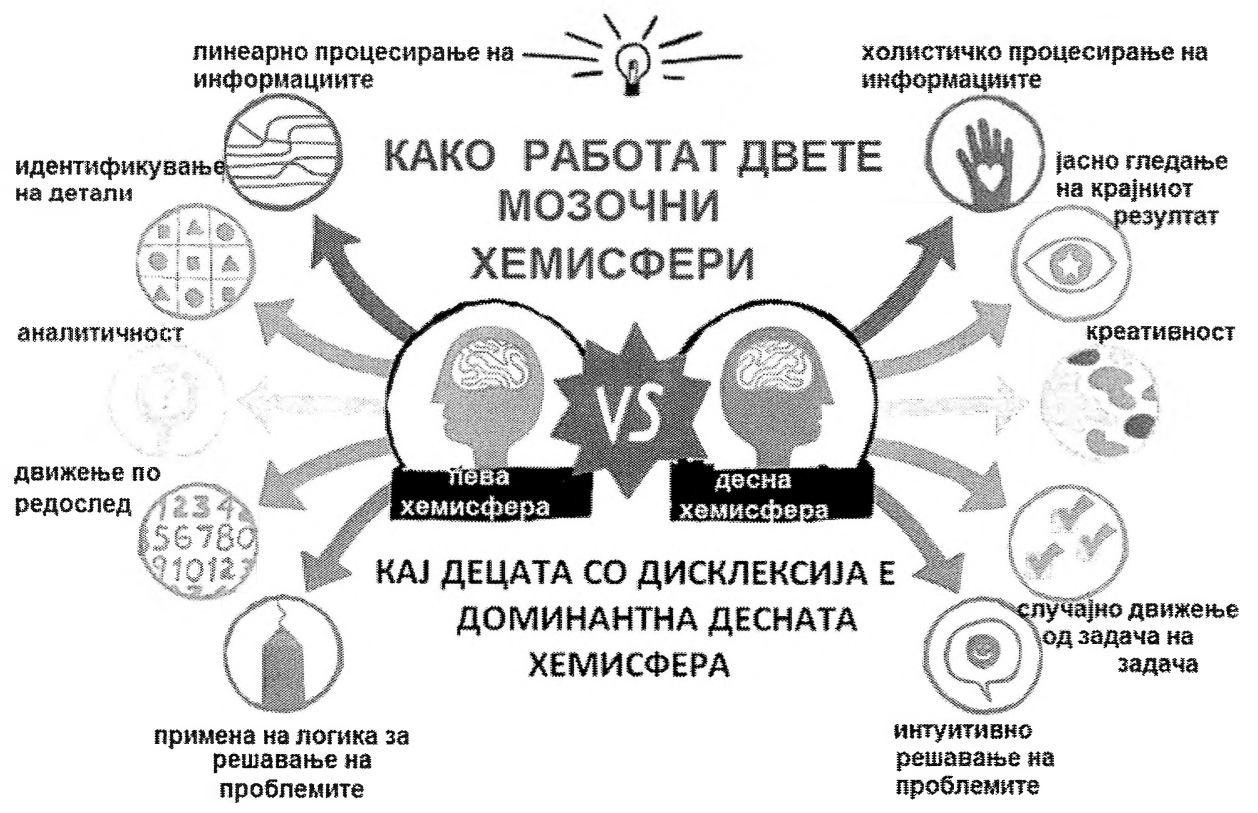

СЛИКА 1. МОЗОЧНИ ЦЕНТРИ ВО ЛЕВАТА И ДЕСНАТА ХЕМИСФЕРА (ПРРЕЗЕМЕНО ОД ВЕБ-СТРАНИЦАTA HA INTERNATIONAL DYSLEXIA ASSOCIATION)

Карактеристики за лицата со дислексија се непостојаност, непредвидливост и варирање на способностите од ден на ден и од час на час.

Општи знаци кои упатуваат на специфични тешкотии во учењето се следниве:

- нормална или дури и натпросечна интелигенција (IQ $\geq 90$ );

- неусогласеност помеѓу интелигенцијата и постигнувањето;

- заостанување во постигнувањата во специфични области;

- пречки во вниманието и голема расеаност; 
- слаба моторна координација;

- перцептивни пречки (како искривување на гласовите, буквите, зборовите и бројките);

- тешкотии во просторната ориентација;

- тешкотија со мотивацијата и саморегулација на однесувањето,

- специфични пречки на помнењето и говорот;

- незрелост во социјалните вештини;

- неразвиена вештина на учењето.

Треба да се истакне дека за повеќето деца со специфични тешкотии во учењето најголем проблем е совладувањето на читањето. Дислексија е термин кој се користи за пречки во читањето поврзани со невролошките фактори кои доведуваат до тешкотија во примањето и преработката на видните дразби во централниот нервен систем. Главни показатели за дислексија ce (Golubović, 2000):

- тешкотии во поврзувањето на буквата и гласот;

- замена на графички сличните букви (б-д, м-н, с-3, ш-т, добар - бодар, бебе - деде, нема - мене);

- додавање букви кои не постојат во зборовите;

- погодување на зборовите;

- структурни промени во зборот - преместување или вметнување на букви (врата - трева, ниво - вино);

- замена на фонетски слични букви (д-т, г-к, б-П, з-с, држи - тржи, бере пере, грее - крие);

- замена на слогови (он - но, еј - је, ние - ине, до - од);

- замена на зборови (мрачен - мачка, добар - обад);

- додавање букви и слогови (брада - барада, мравка - марква);

- повторување на делови од зборот (насмеанан, рамемења);

- тешкотии во следењето на низите на буквите или бројките (слон - солон, 21 - 12);

- тешкотии во следењето на насоката на читањето (горе - долу, лево - десно);

- враќње на веќе прочитаниот ред;

- изоставање зборови и цели редови;

- изоставање на еден збор или цел ред;

- читање на еден збор на неколку погрешни начини.

Неспецифични тешкотии поврзани со читањето што може да ги имаат и децата кои немаат дислексија:

- бавност, различни блокади и паузи;

- читање напамет и по прилика;

- нејасна и површинска артикулација;

- слабо разбирање на прочитаното. 


\section{Области во кои може да имаат проблем децата со дислексија}

Многу дефиниции на дислексијата укажуваат на тоа дека слабата работна меморија е највообичаена карактеристика на дислексијата. Всушност, се работи за дискрепанца помеѓу работната меморија и способноста за резонирање, која е потврдена во многу истражувања на дислексијата. На пример, направена е анализа на тест-резултатите на 443 студенти во високото образование (Lawrence, 2009). Изборот на студентите е направен врз основа на осумгодишен период на тестирање на изгледите за дислексија. Сите тие истражувања покажале дека студентите имале тешкотии во академското учење. Добиено е дека 94,6 проценти од студентите тестирани со тестот за мерење на интелигенција (Wechsler Intelligence Scales) покажуваат значајна дискрепанца помеѓу скоровите на суптестовите кои ја мерат работната меморија и скоровите на суптестовите кои ја мерат способноста за резонирање и во вербалните и невербалните форми. Останатите 5,4 проценти имале други причини за тешкотиите во учењето, како што се недостаток на способности, мотивација, Скотопски синдром (неможност да чита на бела хартија) или емоционални проблеми.

Постојат докази (Hulme, 1981; Jorm, 1983; Siegal\&Linder, 1984 според Golubović, 2000) дека дислексичните деца типично лошо ги работат задачите на помнење броеви кои се задачи за краткотрајно помнење. Исто такам забележано е дека зборовите што се римуваат помалку ги запамтувале од зборовите што не се римуваат. Тешкотиите на краткотрајната меморија може да доведат до тешкотии во меморирање на парцијално декодираните зборови во мислите и може да се замени со зборови кои се наоѓаат во долготрајната меморија (Hulme \& Snowing, 1992 според Golubovic, 2000). Некои автори сметаат дека неспособноста на задржување на сликата на зборот во меморијата е основна тешкотија која ја покажуваат дислексичните деца. На ова укажуваат и практичните искуства кои потврдуваат дека децата со тешкотии во читањето и пишувањето, и покрај многубројни повторувања, не можат да ја запомнат сликата на зборот.

Тешкотиите во анализата на зборовите во реченицата, послабата способност за учење текст напамет, сиромашен речник и изразена тешкотија во прераскажување, задоцнет развој на говорот и пречки во артикулацијата се толкуваат со неспособноста за задржување на сликата на зборот во помнењето. Дури и грешките во препишувањето (од табла или од друг текст) се должат на слабоста на т.н. непосредно или краткотрајно помнење.

Тешкотиите во читањето може да се поврзани и со дефицит на визуелна периепиија кај децата со дилексија (визуелна дислексија) (Lawrence, 2009). Тие не можат во меморијата да ги задржат дискретните разлики што постојат помеѓу некои букви, бројки и форми. Посебна тешкотија се јавува помеѓу сличните букви. Кај овие деца е многу тешко да ги запомнат сликите на зборовите меѓу кои има големи сличности. Тие најчесто читаат на глас за да можат визуелниот дефицит да го компензираат со аудитивен прием на информациите. На овие ученици им е тешко да запомнат како изгледа некој збор, па еден ист збор кој веќе го прочитале им е тешко да го препознаат на следната страница. Исто така им е тешко препи- 
шување од табла, потребно им е повеќе време бидејќи тешко го помнат зборот што го виделе.

Неспособноста за аудитивна перчепиија и диференцијацијата на фонемите (аудитивна дислсксија - глувост за фонеми), исто така, е значајна тешкотија кај децата со дислексија. Тоа значи дека децата не можат аудитивно да ги разликуваат фонемите кои се слични по звучност, па така често доаѓа до конфузија (а o, o-y, е - и). Тие, исто така, не ја слушаат разликата во акцентирањето на сложените зборови или, пак, завршетокот на зборот (обично го изоставаат последниот глас). На пример, кај учениците со дефицит на оваа вештина може зборот тринаесет да им звучи исто како триесет.

\section{Емоционални и социјални проблеми кај децата со дислексија}

Детето кое има тешкотии во читањето и пишувањето, а не наидува на разбирање и помош ниту во семејството ниту во училиштето често наоѓa решение во различни невролошки реакции. Така невротските пречки стануваат придружни симптоми на дислектичните симптоми, а понекогаш и доминантен проблем, кој доведува до социјални, емоционални и едукативни проблеми, кои, од друга страна, ги зголемуваат дислектичните пречки. Во едно истражување на Gates (1941, според Golubović, 2000) е утврдено дека сериозните нарушувања во читањето кај околу $75 \%$ од децата предизвикуваат проблеми во приспособувањето на личноста, а кај околу $25 \%$ од случаите емоционалните тешкотии придонесуваат во тешкотиите во читањето. Харис (Golubović, 2000), пак, сметал дека и кај децата со тешкотии во читањето можат да се пронајдат емоционално здрави деца, некои многу инхибирани „добри“ деца, некои со невротични симптоми, некои со забележливи знаци на лошо однесување, некои пределиквентни и некои претпсихотични и психотични деца.

\section{Самодовербата кај дещата со дислексија}

Самодовербата е најпосакувана лична карактеристика кај луѓето, а особено кај децата со дислексија. За жал, децата со дислексија се особено под ризик од развој на ниска самодоверба. Ова не е поради тоа што тие често се чувствуваат неадекватни кога се споредуваат себеси со другите деца, но, исто така, и како резултат на многу фрустрации кои често ја придружуваат дислексијата. На пример, не е лесно да се покажува самодоверба пред други ако секогаш забораваш што тие кажале или си бавен во реакцијата. Ова се случува често кај децата со дислексија и дома и на училиште. Постојат докази за силната врзаност помеѓу вештината за читање и самодовербата (Lawrence, 2006). Децата со висока самодоверба обично подобро ги вршат училишните обврски од оние со ниска самодоверба. Но, исто така, самодовербата и училишните постигнувања се во реципрочна врска. Ниската самодоверба влијае на постигнувањето и ниското постигнување влијае на самодовербата. Постојат истражувања кои покажуваат дека високата самодоверба не е поврзана само со училишните постигнувања, но, исто така, и со емоционалното приспособување и физичкото здравје. Така, децата со висока самодоверба се поздрави, посреќни, повеќе се мотивирани да постигнуваат успеси во училиштето и 
имаат помалку бихевиорални проблеми. Истражувањата на Куперсмит и Бандура (Coopersmith, 1967; Bandura, 1977) покажуваат дека родителите со висока самодоверба, генерално, имаат деца со висока самодоверба. За да се подигне самодоверба не е доволно децата само да се пофалуваат за нивното постигнување, туку таа пофалба да биде за вистинското вложување труд и успех. Најважно е децата високо да се вреднуваат себеси без оглед на нивното постигнување. Децата со дислексија често се склони да имаат неуспеси до одреден степен, но тие не се сами по себе доволна причина за ниска самодоверба. Учењето со обиди и грешки е неизбежен процес за повеќето деца, а особено за децата со дислексија. Ниската самодоверба кај децата се манифестира на различни начини во зависност од индивидуалниот темперамент на децата. Постојат ефективни методи, стратегии и програми кои ги подобруваат комуникациските вештини и кои ја овозможуваат самодовербата на децата (Gordon, 2003; Dinkmeyer \& Mc Kay, 1976).

\section{Идентификување на дислексијата}

Првиот чекор при справување со дислексијата е да се комплетира прелиминарното набљудување, вклучувајќи дискусии со родителите и учениците. Идентификувањето на дислексијата не значи дијагностицирање на дислексија и детална процена. За почеток е доволно наставникот да набљудува на што најмногу греши ученикот и да ги утврди евентуалните причини. Постојат многу процедури за идентификување на дислексијата кај одредени ученици во одделението. Овде ќе се задржиме на информативниот пристап кој произлегува од наставната практика (Golubović, 2000).

\section{Интервју со ученикот}

Од разговор со ученикот можете да дознаете многу за него. Затоа одвојте време и разговарајте со ученикот во тивка атмосфера надвор од погледите на соучениците. Со поставување прашања ќе дознаете што е за него лесно, а што е тешко и кои стратегии ги применува за учење. Пристапете му на ученикот пријателски за да ја почувствува вашата желба да му помогнете. Еве некои прашања што може да му ги поставите:

- Кога читаш, што се случува со зборовите на страницата?

- Дали брзо се заморуваш кога читаш или пишуваш? Дали ти се заматуваат буквите? Или можеби мрдаат?

- Дали понекогаш те боли главата или стомакот кога читаш?

- Како се чувствуваш кога треба да прочиташ нешто на глас?

- Што е лесно а што е тешко кога пишуваш?;

- Како ги препишуваш зборовите од табла? Дали го гледаш целиот збор и го пишуваш или ја гледаш секоја буква посебно?

- Дали го губиш редот кога пишуваш или читаш?

- Како се чувствуваш кога ќе ти дадам неколку задачи одеднаш, на пример: да ја отвориш читанката на одредена страница и да прочиташ некој дел од текстот?

- Дали ти е тешко да запомниш што ви задавам за домашна задача? 
- Дали ти пречи кога има врева во одделението?

Треба да бидете внимателни и да ги поставувате прашањата преку разговорот со ученикот, за да не се почувствува дека го тестирате или го испрашувате. На овој начин воспоставувате пријателска комуникација со ученикот. Забележете ги одговорите на ученикот.

Набљудување

Во текот на секојдневните часови можете да го набљудувате ученикот за кого сте загрижени и кај кого сте забележале тешкотии во учењето. Набљудувањето треба да биде насочено кон следново:

- различно ниво на способности во различни области;

- разлики меѓу знаењето кое ученикот го покажува при усна и писмена проверка на знаењето;

- брзина и точност на одговорите при вербални инструкции;

- точност при читање;

- колку е течно читањето;

- брзина на читање;

- разбирање на прочитаното.

Разговор со родителите

Повеќето родители се среќни кога разговараат за своите деца. Понекогаш тие се свесни за одредени тешкотии со кои се сретнува детето, но тоа не е секогаш така и не се такви сите родители. Родителите се осетливи кога ќе бидат повикани во училиште поради одредени тешкотии во учењето на нивното дете. Доколку наставникот согледал тешкотии при читањето и пишувањето кај некој ученик, тој би требало да ги извести родителите. Многу е важен начинот на кој ќе се разговара со родителите. Првата средба треба да биде информативна и тоа е најдобрата стратегија за почеток.

Родителите можат да бидат одличен извор на корисни информации кои ви се потребни за ученикот: какво е однесувањето дома, дали има одбивност кон одење на училиште, на кој начин ги работи домашните задачи и др.

Откако ќе воспоставите двонасочна комуникација со родителите, добро е да ја пополните листата на проверки заедно со нив. Обезбедете копија од пополнетата листа за родителите за да можат внимателно да ја разгледаат дома.

Откако ќе го разбудите интересот на родителите за тешкотиите на нивното дете, тогаш треба јасно да им предочите во кои делови вие како наставник можете да му помогнете на ученикот.

\section{Распространетост на дислексијата во светот и кај нас}

Во нашиот образовен систем дислексијата не е евидентирана како присутен проблем кај одреден број ученици со тешкотии во учењето. Во Република Македонија досега не се направени истражувања за бројот на лица кои страдаат од 
дислексија, но истражувањата во развиените земји покажуваат дека во англиското говорно подрачје дислексијата е застапена кај околу $15 \%$ од луѓето, а во словенското говорно подрачје кај $10 \%-15 \%$. Во хрватската популација, истражувањата покажуваат дека $5 \%$ од децата во едно одделение имаат дислексија. Може да се претпостави дека словенските јазици се транспарентни јазици поради што и процентот на застапеност на дислексијата е понизок.

Во нашата земја, Здружението за дислексија „Ајнштајн“ во 2015 година изврши тестирање на 782 ученици од две средни училишта во Скопје. Тестот со кој учениците вршеа самопроцена на дислексијата беше преземен од Листата за проверка на дислексија од авторите Кавклер, Магајна, Кошак Бадуер, Јанзељ, Андрејчик и Земјак (Golubović \& Golubović, 2010). Добиените одговори покажуваат дека околу $10 \%$ од учениците манифестираат знаци на дислексија. Овој податок укажува на потребата од дејствување на полето на дислексија во Република Македонија.

\section{Заклучок}

Читањето е комплексен процес што се состои од многу подвештини, така што во процесот на учење на читање детето со дислексија секогаш ќе наидува на тешкотии. Читањето е главна вештина во учењето на учениците и поради тоа дислексијата создава тешкотија во учењето. Може да се каже дека дислексијата е повеќедимензионална тешкотија во учењето. Фактот што дислексијата има повеќе карактеристики е причина за тоа што понекогаш е тешко да се идентификува. Многу деца покажуваат некои знаци на дислексија во раниот развоен период, што не значи дека во училишниот период ќе пројават дислексија. Друга причина зошто дислексијата е тешко да се идентификува е дека некои деца се способни да ја маскираат нивната дислексија користејќи многу стратегии да за да се избегне неуспех или, пак, да не биде виден од другите. Рековме дека дислексијата има повеќе форми, така што едноставното објаснување на тоа дека детето има дислексија не кажува ништо за природата на неговите тешкотии во учењето, односно читањето. Во насока да го разбереме дислексичното дете, важно е да ја знаеме возраста на детето, како дислексијата се манифестира и во колкав степен.

Сѐ уште не постои меѓународен консензус околу дефиницијата на дислексијата од три причини: првата е мултидимензионалната природа на дислексијата, потоа, втората потекнува од различните истражувања и, на крај, третата е тенденцијата кон вклучување други видови специфични тешкотии во учењето во една дефиниција. Новата дефиниција ја вклучува различноста, причинските и дескриптивните фактори и може да е применлива и за деца и за возрасни. Се настојува дефиницијата да биде модифицирана во насока на идните истражувања кои треба да ја вклучат забелешката дека дислексијата е повеќе различност во функционирањето отколку слабост.

Истражувањата покажуваат дека причините за дислексија имаат биолошка природа, односно генетско потекло. Најчесто децата со дислексија имаат родител или некој близок роднина што имал дислексија. 
Родителите обично прашуваат кои тестови се употребуваат за да се процени дислексијата. Наставниците се обично првите кои може да се посомневаат во дислексија кај детето, така што листите за проверка на симптомите на дислексија се популарни алатки кои наставниците можат да ги употребат.

Истражувањата покажуваат дека постои поврзаност помеѓу самодовербата на детето и неговото академско постигнување и бихевиорални проблеми. Децата со дислексија се особено под ризик за развивање ниска самодоверба доколку не се идентификувани порано и не добијат соодветна помош. Децата со висока самодоверба се повеќе мотивирани да постигнуваат успеси во училишната работа, а имаат и помалку бихевиорални проблеми. Детето кое има тешкотии во читањето и пишувањето, а нема разбирање и помош од страна на семејството и училиштето, често пројавува анксиозност и други невролошки проблеми. Така невротските пречки стануваат додатни симптоми на дислексичните симптоми, а понекогаш се и доминантни проблеми што доведуваат до социјални, емоционални и едукативни проблеми кои, од друга страна, повторно ги зголемуваат дислексичните пречки.

Во нашата земја дислексијата не е доволно истражувана, но, сепак, одредени процени укажуваат на релативно голем процент на ученици кои патат од дислексија. Таа, како различност во когнитивниот пристап во учењето кај учениците не е вклучена ниту во законските одредби на образовниот систем како што е во понапредните земји во светот. Ова укажува на потребата од професионално интервенирање во полето на дислексијата, како и на потребата од повеќе научни истражувања во оваа област. 


\section{Литература}

Bandura, A. (1977) Self-efficacy: Toward a unifying theory of behavioral change. Psychological Review, 84, 191-215.

Coopersmith, S. (1967) The Antecedents of Self-Esteem. San Francisco, CA: Freeman Press.

Dinkmeyer, D., Mc Kay, G., D. (1976) The Parents Handbook: Systematic Training for Effective Parenting, Circle Pines, MN: American Guidance Service.

Golubović, S. (2000) Disleksija, Beograd, Univerzitetska praksa.

Golubović, S., Golubović, Z. (Ed.) (2010) Disleksija - Vodič za samostalno učenje studenata sa disleksijom, Beograd, Univerzitet u Beogradu.

Gordon, T.(2003) Teacher effectiveness training. First Revised Edition. New York: Three Rivers Press.

Lawrence, D. (2006) Enhance Self - Esteem in the Classroom, Sage Publications Ltd.

Lawrence, D. (2009) Understanding Dyslexia - A Guide for Teachers and Parents, Berksire, England, The McGrow-Hill Companies.

Vizek-Vidović, V., Rijavec, M., Vlahović-Stetić, V., Miljković, D. (2003) Psihologija obrazovanja, Zagreb, IEP VERN, (Udžbenici Sveucilišta u Zagrebu).

Извештај од истражување на Здружението за дислексија - „Ајнштајн“, Општина на Град Скопје, 2015. 
Orhideja SHURBANOVSKA

\section{SPECIFIC DIFFICULTIES IN LEARNING AMONG STUDENTS - DYSLEXIA}

\section{Summary}

Dyslexia is topic for discussion which last for decades and furthermore is subject for itself. British Association for Dyslexia give the best definition for dyslexia as combination of abilities and difficulties which affects on reading process, spelling and writing. In association are weakness as processing the information, short-term memory, concentration, sequencing, and organization, audit and/or visual perception, speech language and motor skills.

In our country, in 2015, Macedonian Association for Dyslexia „Einstein" conducted testing on 782 students, from two secondary schools in Skopje. The test for student's self estimation of dyslexia was taken over from the authors Kavkler, Magajana, Koshak-Baduer, Janzelj, Andrichek and Zemjak. The obtained data shows that approximately $10 \%$ of the students manifest signs of dyslexia. This information leads us to invest more forces in the field of dyslexia, in order to facilitate the learning difficulties of students with dyslexia in our country.

Keywords: DIFFICULTIES IN LEARNING, DYSLEXIA, STUDENTS 